\title{
IMPLIKASI PELAKSANAAN PROGRAM DANA DESA TERHADAP KOHESI SOSIAL DI DESA TAMALATE KABUPATEN TAKALAR
}

\author{
Muhammad Faisal dan Umar Nain \\ Program Studi Pembangunan dan Pemberdayaan Fakultas Politik Pemerintahan, \\ Institut Pemerintahan Dalam Negeri, Kampus Sulawesi Selatan \\ E-mail: faisalmile69@gmail.com
}

\begin{abstract}
ABSTRAK, Tujuan penelitian ini adalah untuk menganalisis implikasi pelaksanaan program dana desa terhadap kohesi sosial. Pelaksanaan program dana desa menjadi penting untuk dianalisis karena kehadirannya adalah untuk memperkuat masyarakat desa sebagai subjek pembangunan.Jenis penelitian ini adalah korelasional prediktif, non eksperimental. Data diperoleh melalui instrumen berupa kuesioner. Responden penelitian ini adalah 265 warga Desa Tamalate (198 laki-laki, 67 perempuan)yang diambil dengan teknik convenience sampling, insidental, dan secara purposif diupayakan agar responden dapat dijaring pada setiap RW dari 10 RW di Desa Tamalate dan berasal dari berbagai latar belakang pekerjaan. Data penelitian dianalisis dengan menggunakan uji regresi linear satu variabel independen dan dengan bantuan Program SPSS versi 20. Hasil penelitian menunjukkan bahwa pelaksanaan program dana desa berimplikasi positif dan siginifikan terhadap kohesi sosial masyarakat. Dari persamaan regresi linear diperoleh informasi bahwa pelaksanaan program dana desa berkontribusi sebesar 0,539 terhadap kohesi sosial. Nilai R Square sebesar 0,300 yang menjelaskan bahwa sebanyak 30\% variasi yang berbeda dari kohesi sosial ditentukan oleh pelaksanaan program dana desa pada taraf signifikansi $=0,05$. Kohesi sosial tercipta seiring dengan munculnya rasa suka diantara anggota masyarakat dan interaksi yang terjadi didominasi kerjasama serta mempunyai tujuan yang terkait satu dengan lainnya.
\end{abstract}

Kata kunci: Implikasi; pelaksanaan program; dana desa; kohesi sosial

\section{IMPLICATIONS FOR THE IMPLEMENTATION OF VILLAGE FUND PROGRAMS TO SOCIAL COHESION IN TAMALATE VILLAGE TAKALAR REGENCY}

\begin{abstract}
The purpose of this study was to analyze the implications implementing the village fund program on social cohesion. The implementation village funding program becomes important analyzed because presence is strengthen the village community the subject development. Types of research correlational predictive, non experimental. Data of research variables obtained through instrument form questionnaires the data participants who happened. Participants this study were 265 Tamalate villagers (198 men, 67 women) for field research. Participants were captured convenience, incidental, and purposive sampling techniques attempted enable participants captured each RW of $10 \mathrm{RWs}$ in Tamalate Village and from various occupational backgrounds. Research data were analyzed by using linear regression test one independent variable and help SPSS program version 20. The results showed implementation the village fund program has positive and significant implications for social cohesion. From the linear regression equation is found implementation of village fund program contributes 0.539 to social cohesion. The $R$ Square value of 0.300 explains that many as $30 \%$ the different variations social cohesion are determined the implementation village fund program at significance level $=0.05$. Social cohesion is created along with emergence a sense of love among members society and interaction occurs dominated cooperation and have goals related to one another.
\end{abstract}

Key words: implications; program implementation; village funds; social cohesion

\section{PENDAHULUAN}

Bahwa salah satu dari Nawa Cita Presiden Jokowi-JK adalah membangun Indonesia dari pinggiran dengan memperkuat daerah-daerah dan desa dalam kerangka negara kesatuan. Sebagai upaya memperkuat daerah-daerah dan desa di seluruh Indonesia maka dikucurkan program dana desa dengan alokasi anggaran trilliunan rupiah.Secara filosofi, dana desa adalah untuk memberdayakan masyarakat desa, agar desa menjadi kuat, maju, mandiri, dan demokratis sehingga dapat menciptakan landasan yang kuat dalam melaksanakan pemerintahan dan pembangunan menuju masyarakat yang adil, makmur, dan sejahtera.Penggunaan dana desa sebagaimana diatur dalam Peraturan Pemerintah Nomor 60 Tahun 2014 pada pasal 19 disebutkan bahwa dana desa digunakan untuk membiayai penyelenggaraan pemerintahan desa, pelaksanaan pembangunan, pembinaan kemasyarakatan, dan pemberdayaan masyarakat. Walaupun demikian, dana desa lebih diprioritaskan untuk membiayai kegiatan pembangunan dan pemberdayaan masyarakat desa. Selanjutnya, disebutkan pula dalam pasal 20 bahwa penggunaan dana desa harus mengacu kepada rencana pembangunan jangka menengah desa (RPJMDesa) dan rencana kerja pemerintah desa (RKPDesa). Lebih jauh, dalam Peraturan Menteri Desa, Pembangunan Daerah Tertinggal dan Transmigrasi Nomor 21 Tahun 2015 tentang Penetapan Penggunaan Prioritas Dana Desa dijelaskan bahwa tidak membatasi prakarsa lokal dalam merancang program atau kegiatan pembangunan prioritas yang dituangkan ke dalam dokumen rencana kerja pemerintah desa (RKPDesa) serta anggaran pendapatan dan belanja desa (APBDesa) melainkan memberikan pandangan prioritas dana desa, sehingga desa tetap memiliki ruang untuk 
berkreasi membuat program atau kegiatan desa sesuai dengan kewenangannya, analisis kebutuhan prioritas dan sumber daya yang dimilikinya. Meskipun desa diberikan kewenangan dalam penggunaan dana desa, namun tetap memperhatikan prinsip-prinsip penggunaan dana desa. Adapun prinsip-prinsip penggunaan dana desa adalah sebagai berikut: 1) keadilan, berarti setiap warga masyarakat memiliki hak yang sama dalam memanfaatkan dana desa. Jadi kepentingan warga desa tidak dibeda-bedakan dalam pemanfaatan dan menikmati hasil pembangunan yang dibiayai dari dana desa, (2) kebutuhan prioritas, dalam arti lebih mengutamakan kebutuhan masyarakat yang lebih mendesak, sehingga dapat memecahkan secara langsung berbagai persoalan yang menjadi kebutuhan masyarakat desa dan (3) tipologi desa, dengan mempertimbangkan keadaan potensi sumber daya alam dilihat dari karakteristik wilayah desa seperti desa pesisir/ pantai, desa dataran rendah, dan desa pegunungan yang didukung dengan sumber daya manusianya (Nain, 2017: 219).

Penyelenggaraan prioritas dana desa adalah pada dua bidang yaitu program atau kegiatan pembangunan desa dan pemberdayaan masyarakat desa. Untuk meningkatkan kesejahteraan masyarakat desa dan kualitas hidup manusia serta penanggulangan kemiskinan, maka program atau kegiatan pembangunan desa meliputi: (i) pembangunan infrasruktur untuk mengatasi isolasi desa sehingga ada konektivitas antara satu desa dengan desa lain; (ii) pembangunan sarana pelayanan kesehatan berbasis masyarakat seperti posyandu dan pos kesehatan desa serta penempatan tenaga medis di desa dalam rangka mendekatkan pelayanan kesehatan kepada masyarakat desa; (iii) pembangunan infrastruktur pendidikan anak usia dini, kelompok bermain, dan taman kanak-kanak di desa serta didukung dengan pembangunan perpustakaan desa; (iv) pemberdayaan usaha ekonomi lokal menuju peningkatan produk unggulan desa yang memiliki daya saing; atau (v) menciptakan inovasi desa yang menghasilkan energi terbarukan seperti biogas dari kotoran ternak yang tidak merusak sehingga menunjang keberlanjutan lingkungan hidup (Nain, 2016: 160). Dalam istilah lebih khusus, program pembangunan akan berhasil jika ada kesesuaian yang erat antara: kebutuhan pihak penerima bantuan dengan hasil program; persyaratan program dengan kemampuan nyata dari organisasi pembantu, dan kemampuan pengungkapan kebutuhan oleh pihak penerima dan proses pengambilan keputusan organisasi pembantu (Korten, 1988: 240).

Tata cara pelaksanaan penyusunan rencana pembangunan jangka menengah desa (RPJMDesa) dimulai dari persiapan, musyawarah dusun, musyawarah perencanaan desa, musyawarah perencanaan pembangunan desa dan sosialisasi. Pada kegiatan persiapan melakukan sosialisasi dan pembentukan kelompok kerja/tim perencanaan desa yang dilanjutkan dengan penguatan kapasitas kelompok kerja/tim perencanaan desa, penyusunan Road Map, identifikasi kebutuhan data sekunder desa, dan sosialisasi jadwal ke masing-masing dusun (Nain, 2017: 102). Ini menjelaskan bahwa sejak tahapan penyusunan RPJMDesa sudah ada aksi kolektif dari kelompok kerja dan masyarakat dusun. Masyarakat desa diharapkan untuk ikut dalam sosialisasi kegiatan, sehingga mereka memahami poin-poin penting dalam penyusunan Rencana Pembangunan Jangka Menengah (RPJMDesa) termasuk dapat berkontibusi memberikan saran atau gagasan dan terlibat dalam pengambilan keputusan dalam perencanaan pembangunan desa. Pada tahap musyawarah dusun (Musdus) keterlibatan masyarakat desa sangat diperlukan. Aset desa dan permasalahan dasar masyarakat digali pada tahap ini. Olehnya itu, partisipasi masyarakat dusun sangat diperlukan untuk mengetahui secara tepat apa kebutuhan masyarakat yang mendasar dan dibutuhkan oleh masyarakat desa pada umumnya. Kehadiran masyarakat dari berbagai latar belakang pekerjaan seperti petani, nelayan, pengrajin, atau lainnya mutlak diperlukan supaya rencana pembangunan yang disusun itu tidak salah sasaran. Aksi koleksif masyarakat dan kekokohan kelembangaan masyarakat desa menjadi poin penting demi terciptanya kohesi sosial masyarakat tidak saja pada tahap persiapan, musyawarah dusun, sampai kepada pelaksanaan musyawarah perencanaan pembangunan desa, tetapi juga sampai pada pelestarian dan pemanfaatan hasil-hasil pembangunan. Aksi kolektif, kekokohan kelembagaan, dan kerjasama semua pemangku kepentingan merupakan unsur penting dan merupakan faktor instrik masyarakat dalam membangun desa demi terwujudnya kohesi sosial masyarakat.Pelaksanaan program dana desa dimulai dengan menyusun rencana pembangunan jangka menengah desa (RPJMDesa) yang sesuai dengan tata cara/tahapan penyusunan yaitu mulai dari persiapan, musyawarah dusun, musyawarah desa, musyawarah perencanaan pembangunan desa, dan sosialisasi peraturan desa tentang rencana pembangunan jangka menengah desa (RPJMDesa) untuk enam tahun. Selanjutnya adalah menjabarkan rencana pembangunan jangka menengah kepada rencana kerja pemerintah desa (RKPDesa) untuk satu tahun, serta dilanjutkan dengan menyusun rencana anggaran pendapatan dan belanja desa (RAPBDesa). Program atau kegiatan yang disusun dalam rencana anggaran pendapatan dan belanja desa (RAPBDesa) itulah yang dilaksanakan untuk periode pembangunan desa satu tahun anggaran.

Kehadiran program dana desa memengaruhi pola interaksi masyarakat desa. Jika sebelumnya, masyarakat desa memiliki tingkat homogenitas yang tinggi dengan solidaritas mekanik, maka setelah dana desa masuk ke desa-desa terjadi perubahan menjadi masyarakat heterogen. Masyarakat heterogen ditandai dengan solidaritas organis (Johnson, 1986: 183). Perkembangan masyarakat desa dari solidaritas mekanis menjadi solidaritas organik ditandai dengan adanya pembagian kerja (Soekanto, 2013: 35). Dengan Dana desa yang 
penggunaannya dikuasakan kepada kepala desa, maka terdapat kecenderungan kepala desa untuk mengorganisir masyarakatnya dalam kelompok-kelompok kegiatan yang dibiayai dari dana desa sebagai wujud nyata dari kegiatan pemberdayaan masyarakat. Ini berarti bahwa interaksi dapat dilihat sebagai proses sosial. Sebagai suatu proses sosial interaksi merupakan salah satu faktor yang memengaruhi kohesivitas sosial masyarakat. Sudah tentu interaksi masyarakat dapat terjadi mulai pada tahap persiapan, musyawarah dusun (musdus), musyawarah desa (musdes), musyarawah perencanaan pembangunan desa (musrenbangdes), dan tahap sosialisasi peraturan desa tentang rencana pembangunan desa. Faktor-faktor yang dapat membentuk kohesifitas adalah setiap anggota memiliki komitmen yang tinggi, interaksi didominasi kerjasama bukan persaingan, mempunyai tujuan yang terkait satu dengan lainnya (Faturochman (2006: 95). Pembangunan desa yang dimulai dari tahapan perencanaan dengan melibatkan masyarakat desa akan tercipta bentuk interaksi yang didominasi kerjasama dan sama-sama mempunyai tujuan yang saling terkait dengan lainnya. Oleh karena itu, dalam penelitian ini diasumsikan bahwa program dana desa yang penggunaannya dimulai dengan menyusun rencana pembangunan jangka menengah desa (RPJMDesa), menyusun rencana kerja pemerintah desa (RKPDesa), menyusun rencana anggaran pendapatan dan belanja desa (RAPBDesa) desa, sampai kepada membuat pertanggungjawaban pelaksanaan dan pelestarian serta pemanfaatan hasil-hasil pembangunan desa akan berkorelasi dengan tingkat kohesivitas masyarakat desa.

Kohesi sosial dapat dipahami sebagai kesatuan, keutuhan dan kepaduan dalam suatu upaya agar anggota kelompok tetap bertahan di dalam komunitas (Kaslan, 2014:7). Menurut Kulig et al. (2008: 83-84) komunitas pedesaan memiliki karakteristik yang berbeda dari komunitas lainnya, yakni memiliki latar belakang yang sama dengan tingkat pendidikan yang setara, afiliasi keagamaan, dan etnik, juga rentang waktu masyarakat berada dalam komunitas tersebut. Homogenitas ini membuat kohesi sosial pada komunitas pedesaan relative lebih tinggi daripada komunitas perkotaan. Lebih jauh, Kulig,et al., (2008: 84) memaparkan bahwa komunitas petani memiliki inisiatif dalam mengatasi masalah, saling membantu menanam dan panen serta berinteraksi sebagai aksi kolektif. Selain itu, Forrest, et al., (2001: 2129) menyatakan bahwa ranah-ranah kohesi sosial adalah (1) nilai-nilai bersama dan sebuah budaya warga (civic culture), (2) keteraturan sosial dan kendali sosial, (3) solidaritas sosial, (4) jejaring sosial dan modal sosial, serta (5) kelekatan dan identifikasi pada tempat (place attachment and identity).

Kohesi sosial dalam sebuah komunitas dapat terjadi ketika anggota-anggota komunitas saling menyukai dan menginginkan kehadiran satu dengan lainnya. Kohesi sosial juga dapat terbentuk dari rasa saling percaya (mutual trust) diantara anggota komunitas (Primadona, 2001; Noorkamilah, 2008). Oleh Faisal (2017:72) menyebut trustlahir dari adanya keharmonisan dengan sesama manusia yang dapat berdampak kepada luasnya jaringan kerja. (Myres, 2014: 280). menyatakan bahwa kohesi sosial merupakan perasaan "we feeling" yang mempersatukan setiap anggota menjadi satu bagian. Rasa memiliki tersebut juga dapat membentuk kohesi sosial antar individu dalam suatu komunitas. Rasa memiliki ini yang membuat individu menyadari bahwa ia merupakan bagian dari komunitas. Ramdhani dan Martono (1996: 87) menambahkan bahwa masyarakat yang sudah berkohesi, kepentingan individu sudah tidak diutamakan lagi. Kohesi sosial dapat dilihat dari rasa komunitas (sense of community). Teori rasa komunitas yang dibawa oleh Chavis et.al. (2008: 3) dimana rasa komunitas dapat dilihat dari keanggotan, pengaruh, pemenuhan kebutuhan dan berbagi hubungan emosional. Oleh karena itu, perubahan yang terjadi di dalam komunitas sebagai akibat adanya program dana desa yang berdampak pada aspek ekonomi dan sosial diharapkan tidak menggangu rasa memiliki dan rasa komunitas di Desa Tamalate. Penelitian ini mengkaji bagaimana program dana desa dilaksanakan dan implikasinya terhadap kohesi sosial masyarakat.

\section{METODE}

\section{Jenis Penelitian dan Teknik Analisis Data}

Jenis penelitian ini adalah korelasional prediktif, non eksperimental. Data variabel penelitian diperoleh melalui instrumen berupa kuisioner yang menggali data responden yang sudah terjadi. Oleh karena itu, penelitian ini juga termasuk jenis expost facto. Peneliti tidak melakukan randominasi sampel maupun kontrol variabel.

Data penelitian dianalisis dengan menggunakan uji regresi linear satu variabel independen. Uji regresi digunakan untuk meramalkan suatu variabel dependen (Y) berdasar satu variabel independen (X) dalam suatu persamaan linear (Sugiyono, 2003: 243). Analisis regresi dilakukan dengan menggunakan Program SPSS versi 20. Variabel dependen (Y) adalah kohesi sosial, sedangkan variabel independen (X) adalah Pelaksanaan Program Dana Desa. Menurut Trihendradi (2009: 147), kriteria untuk menentukan apakah model fit (kesesuaian antara model penelitian atau model pengukuran dengan data empiris) adalah jika sig $(0,000)<$ alpha (dalam penelitian ini ditetapkan taraf signifikansi (alpha) sebesar 5\%).

\section{Definisi Operasional Variabel}

Pelaksanaan program dana desa didefinisikan sebagai pelaksanaan program atau kegiatan yang didanai dari dana desa mulai dari keikutsertaan masyarakat dalam penyusunan rencana pembangunan jangka menengah desa, tahap penyusunan rencana kerja pemerintah desa untuk satu tahun, pelaksanaan pembangunan desa, sampai kepada pemanfaatan hasil-hasil pembangunan desa yang pendanaannya bersumber dari anggaran dana desa. Dalam penelitian ini kohesi sosial secara operasional didefinisikan sebagaikesatuan, keutuhan, dan kepaduan 
dalam upaya untuk mendorong anggota tetap bertahan dalam sebuah komunitas. Menurut Chavis et al. (2008: 3) kohesi sosial diukur dengan menggunakan empat indikator yaitu Reinforcement of Needs (pemenuhan kebutuhan), Membership (keterlibatan sebagai anggota komunitas), Influence (memberikan pengaruh) dan Shared Emotional Connection (berbagi kontak emosional). Lebih jauh, Reinforcement of needs (pemenuhan kebutuhan) adalah kondisi dimana anggota komunitas mendapatkan apa yang mereka butuhkan karena telah menjadi bagian dari komunitas, Membership (keterlibatan sebagai anggota komunitas): orang-orang yang tergabung dalam komunitas dan anggota komunitas meluangkan banyak waktu dan usaha mereka untuk menjadi bagian dari komunitas, Influence (memberikan pengaruh): kemampuan komunitas dalam mempengaruhi komunitas lainnya. Selain itu, anggota komunitas juga memiliki pengaruh atas komunitasnya, danShared Emotional Connection (berbagi kontak emosional) adalah anggota-anggota komunitas menikmati kebersamaan di dalam komunitas dan berbagi kejadian penting bersama seperti pesta pernikahan, ulang tahun, dan lain-lain.

\section{Responden Penelitian}

Responden penelitian ini adalah 265 warga Desa Tamalate (198 laki-laki, 67perempuan) untuk penelitian lapangan (field test). Usia responden pada rentang 25-50 tahun. Responden dijaring dengan teknik penyampelan convenience, insidental, dan secara purposif diupayakan agar responden dapat dijaring pada setiap RW dari 10 RW di Desa Tamalate dan berasal dari berbagai latar belakang pekerjaan. Rincian partisipan dari latar belakang pekerjaan tersebuta dalah petani (15), nelayan (143), pedagang (60), industri kerajinan/konstruksi (20), angkutan/jasa-jasa (15), dan pegawai/karyawan (12).

Uji coba instrumen penelitian dilakukan pada 130 warga di Desa Tamalate (75 laki-laki, 55 perempuan) dengan usia berada pada rentang 25-50 tahun. Data uji coba diambil dari berbagai warga pada 10 RW dan 20 RT di Desa Tamalate Kecamatan Galesong Utara Kabupaten Takalar.

\section{Instrumen Pelaksanaan Program Dana Desa}

Instrumen ini disusun sendiri oleh peneliti yang dikembangkan berdasarkan definisi operasional yaitu terkait dengan implikasi program dana desa, meliputi: keikutsertaan masyarakat dalam penyusunan rencana pembangunan jangka menengah desa, tahap penyusunan rencana kerja pemerintah desa, pelaksanaan pembangunan desa, sampai kepada pemanfaatan hasil-hasil pembangunan desa yang pendanaannya bersumber dari anggaran dana desa (24 butir). Alternatif jawaban setiap butir adalah ya atau tidak.

Contoh butir pelaksanaan program dana desa adalah sebagai berikut:

"Pemerintah desa menyampaikan informasi pemahaman kepada masyarakat atas rencana kegiatan yang akan dilaksanakan di desa Tamalate, dengan menggunakan dana desa". Pilihan responnya adalah Ya (Skor 1), atau Tidak (Skor 0). “Saya terlibat dalam kegiatan penyusunan rencana pembangunan jangka menengah desa dan memberikan sasaran/gagasan". Pilihan responnya adalah Ya (Skor 1), atau Tidak (Skor 0)."Dalam rangka mengoptimalkan penggunaan Dana Desa, Pemerintah Desa memprioritaskan bidang pemberdayaan masyarakat dan pembangunan Desa. Pilihannya responnya adalah Ya (Skor 1), atau Tidak (Skor 0).“Ketika program pembangunan di desa dilaksanakan, saya memberikan sumbangan berupa bahan/material bangunan (misalnya: tanah timbunan, pasir, batu kali, semen, dll)". Pilihannya responnya adalah Ya (Skor 1), atau Tidak (Skor 0)."Hasilhasil pembangunan fisik di desa, dapat dilestarikan karena masyarakat desa merasa ikut memiliki”. Pilihan responnya adalah Ya (Skor 1), atau Tidak (Skor 0).

Hasil uji coba instrumen menunjukkan bahwa setiap butir instrumen valid dan reliabel, dengan indeks Cronbach's Alpha 0,862 dan korelasi butir-total 0,294 sampai dengan 0,648.

\section{Instrumen Kohesi Sosial.}

Instrumen ini terdiri atas 20 butir pernyataan yang diadaptasi dari Sense of Community Index version 2/SCI2 (Chavis et al. 2008: 2). Contoh butir pernyataan: "Saya merasakan bahwa saya milik masyarakat Desa Tamalate". Pilihan responnya adalah Ya (Skor 1), atau Tidak (Skor 0). "Saya lebih suka akan tinggal di masyarakat Desa Tamalate ini dibanding di tempat lain”. Pilihan responnya adalah Ya (Skor 1), atau Tidak (Skor 0). "Kebanyakan orang-orang dalam masyarakat Desa Tamalate saling menyukai antara satu dengan yang lain”. Pilihan responnya adalah Ya (Skor 1) atau Tidak (Skor 0). "Apakah orang lain dalam kelompok masyarakat dapat dipercaya". Pilihan responnya adalah Ya (Skor 1) atau Tidak (Skor 0). "Sebagian besar warga Desa Tamalate berbagi tugas dan tanggung jawab untuk membuat masyarakat desa menjadi suatu tempat yang baik untuk kehidupan". Pilihan responnya adalah Ya (Skor 1) atau Tidak (Skor 0). "Orang-orang di Desa Tamalate saling membantu dalam melakukan pekerjaan". Pilihan responnya Ya (Skor 1) atau Tidak (Skor 0). Karena terdapat 20 butir pernyataan, maka kemungkinan skor terendah adalah 0 , yaitu ketika responden memberikan jawaban tidak pada semua butir pernyataan dan skor tertinggi adalah 20, jika responden memberikan jawaban Ya pada semua butir pernyataan. Hasil uji coba instrumen menunjukkan bahwa seluruh butir valid dan reliabel, dengan indeks Cronbach's Alpha 0.862 dengan korelasi butir-total antara 0.437 sampai dengan 0.826 .

\section{HASIL DAN PEMBAHASAN}

\section{Deskripsi Desa Tamalate dan Karakteristik Responden}

Desa Tamalate adalah salah satu desa di Kabupaten Takalar tepatnya di Kecamatan Galesong Utara dengan luas $0,70 \mathrm{~km}^{2}$ yaitu 4,63 persen dari luas kecamatan Galesong Utara. Jarak ke Ibukota Kecamatan hanya 0,5 $\mathrm{km}$, dan sejauh $27 \mathrm{~km}$ dari ibu kota kabupaten. Desa Implikasi Pelaksanaan Program Dana Desa terhadap Kohesi Sosialdi Desa Tamalate Kabupaten Takalar

(Muhammad Faisal dan Umar Nain) 
Tamalate memiliki 4 dusun, 10 RW dan 20 RT.Kecamatan dalam Angka 2016 menjelaskan bahwa jumlah penduduk Desa Tamalate sebanyak 4036 jiwa yang terdistribusi pada 864 rumah tangga, terdiri atas 1896 laki-laki dan 2140 perempuan. Dilihat dari mata pencaharian penduduk, maka Desa Tamalate termasuk desa nelayan, karena kebanyakan penduduknya bekerja sebagai nelayan.

Selanjutnya, karakteristik responden penelitian menurut tingkat pendidikan adalah $37,74 \%$ tamat SD atau sederajat, tamat SMP atau sederajat 28,30\%, tamat SMA atau sederajat $22,64 \%$ dan sebanyak $11,32 \%$ menyelesaikan pendidikannya di tingkat Perguruan Tinggi. Tingkat pendidikan responden menunjukkan lamanya responden menempuh pendidikan formal. Tingkat pendidikan yang hanya tamat SD $(37,74 \%)$ tersebut disebabkan oleh pada umumnya masyarakat nelayan tidak memprioritaskan pendidikan karena tuntutan ekonomi. Setelah anakanak tamat SD, orang tua mereka lebih memilih untuk membawa anaknya untuk mencari ikan. Faktor ekonomi sebagai salah satu alasan rendahnya tingkat pendidikan di Desa Tamalate. Masyarakat berpikir bahwa ketika sudah lulus SD dapat langsung bekerja sebagai nelayan atau di sawah membantu perekonomian keluarga.

Lebihjauh, jenis pekerjaan responden dideskripsikan berikut ini:

\section{Tabel 1. Jumlah dan Jenis pekerjaan responden}

\begin{tabular}{lcc}
\hline \multicolumn{1}{c}{ Jenis Pekerjaan } & Jumlah & Persentase \\
\hline Petani & 15 & 5,66 \\
Nelayan & 143 & 53,96 \\
Pedagang & 60 & 22,64 \\
Industri Kerajinan/Konstruksi & 20 & 7,55 \\
Angkutan \& jasa-jasa & 15 & 5,66 \\
Pegawai/Karyawan & 12 & 4,53 \\
\hline \multicolumn{1}{c}{ Jumlah } & 265 & 100,00 \\
\hline
\end{tabular}

Sumber: Hasil penelitian, 2017

Nelayan merupakan mata pencaharian bagi masyarakat Desa Tamalate yang utama. Hal ini disebabkan oleh letak Desa Tamalate yang berada di pesisir pantai Kecamatan Galesong Utara. Laut yang luas dan segala potensi kekayaan di dalamnya seperti ikan merupakan harapan bagi sebagian besar masyarakat Desa Tamalate. Pekerjaan sebagai nelayan merupakan warisan yang sudah berlangsung cukup lama dari generasi ke generasi. Selain itu, kondisi tersebut juga didukung oleh kurangnya lahan pertanian bagi petani untuk menggarap sawah yang hanya ada di bagian timur desa. Selain bekerja sebagai nelayan (53,96 persen) dan petani (5,66 persen), sebagian warga bekerja sebagai pedagang (22,64 persen), industri kerajinan dan konstruksi (7,55 persen), angkutan dan jasajasa $(5,66)$ serta pegawai/karyawan $(4,53$ persen $)$.

Selanjutnya disajikan pula tingkat pendapatan responden, yaitu pada tabel 2 .

Tingkat pendapatan adalah besarnya jumlah uang yang diterima oleh responden sebagai penghasilan mereka selama bekerja. Tingkat pendapatan dikelompokkan berdasarkan data lapangan yang diperoleh. Pendapatan utama responden berasal dari pekerjaannya sebagai nelayan. Terutama bagi responden yang tidak memiliki keterampilan selain bekerja sebagai nelayan. Walaupun pendapatan warga sebagai nelayan tidak terlalu besar, namun banyak warga di Desa Tamalate tetap bertahan menggeluti pekerjaan sebagai nelayan. Tabel 2 menunjukkan tingkat pendapatan responden yang paling banyak adalah antara 1 juta s.d 2 juta sebesar 52,08 persen, disusul dengan tingkat pendapatan yang kurang dari 1 juta sebesar 29,06 persen. Sedangkan yang lebih dari 2 juta sebesar 11,32 persen.Hubungan antara jenis pekerjaan dengan tingkat pendapatan responden disajikan pada Tabel 3 berikut ini:

Tabel 2. Persentase responden berdasarkan tingkat pendapatan

\begin{tabular}{ccc}
\hline \multicolumn{1}{c}{ Tingkat Pendapatan } & Jumlah & Persentase \\
\hline Kurang dari 1.000.000,- & 77 & 29,06 \\
Antara 1.000.000,- s.d 2.000.000,- & 138 & 52,08 \\
Lebih dari 2.000.000,-- & 50 & 11,32 \\
\hline \multicolumn{1}{c}{ Jumlah } & 265 & 100,00 \\
\hline
\end{tabular}

Sumber: Hasil Penelitian, 2017

Tabel 3 menunjukkan bahwa pendapatan yang kurang dari 1 juta per bulan terbanyak pada jenis pekerjaan responden sebagai nelayan yakni 48 orang, sementara pendapatan lebih dari 2 juta terbanyak pada jenis pekerjaan sebagai pedagang yakni 37 orang dan petani hanya 1 orang. Untuk tingkat pendapatan antara 1 s.d 2 juta terbanyak pada jenis pekerjaan sebagai nelayan yakni 90 orang dan 3 orang responden yang pekerjaannya sebagai petani. Selain itu, tidak ada pegawai/karyawan yang memiliki pendapatan kurang dari 1 juta per bulan. Pegawai/karyawan tersebut enam orang mengaku sebagai perangkat desa dan enam orang lagi berprofesi sebagai karyawan.

Tabel 3. Hubungan antara jenis pekerjaan dengan tingkat pendapatan responden

\begin{tabular}{|c|c|c|c|c|}
\hline \multirow{2}{*}{ Jenis Pekerjaan } & \multicolumn{3}{|c|}{ Tingkat Pendapatan/bulan } & \multirow[b]{2}{*}{ Jumlah } \\
\hline & Kurang dari 1 juta & Antara 1 s.d 2 juta & Lebih 2 juta & \\
\hline Petani & 11 & 3 & 1 & 15 \\
\hline Nelayan & 48 & 90 & 5 & 143 \\
\hline Pedagang & 3 & 20 & 37 & 60 \\
\hline Industri Kerajinan/Konstruksi & 10 & 7 & 3 & 20 \\
\hline Angkutan dan jasa-jasa & 5 & 8 & 2 & 15 \\
\hline Pegawai/Karyawan & - & 10 & 2 & 12 \\
\hline Jumlah & 77 & 138 & 50 & 265 \\
\hline
\end{tabular}




\section{Deskripsi Pelaksanaan Program Dana Desa}

Pelaksanaan program dana desa dimulai pada tahun 2015. Pelaksanaan program dana desa di Desa Tamalate mengacu kepada Rencana Pembangunan Jangka Menengah Desa (RPJMDesa) yang dituangkan dalam Rencana Kerja Pemerintah Desa (RKPDesa) setiap tahunnya. Dengan adanya RPJM Desa dan RKP Desa yang disusun sendiri oleh pemerintah desa bersama Badan Permusyawaratan Desa (BPD) dan masyarakat desa menunjukkan bahwa Desa Tamalate semakin memperkuat hak-hak masyarakat desa dan kewenangan mereka sekaligus mampu mengoptimalkan sumbersumber kekayaan desa baik berupa sumber daya alam maupun sumber daya manusia sebagai kekuatan utama dalam membangun desanya.

Dalam penyusunan RPJM Desa dan RKP Desa, pemerintah desa melibatkan masyarakat di desanya. Hal ini sejalan dengan Peraturan Menteri Dalam Negeri Nomor 114 Tahun 2014 tentang Pedoman Pembangunan Desa yang intinya adalah bahwa dalam perencanaan pembangunan desa perlu mengikuti tahapan kegiatan yang diselenggarakan oleh kepala desa dan perangkatnya dengan melibatkan Badan Permusyawaratan Desa (BPD) dan unsur masyarakat secara partisipatif untuk pemanfaatan dan pengalokasian sumber daya desa secara optimal dalam rangka mencapai tujuan pembangunan desa. Hasil kuesioner penelitian (Tabel 4) menjelaskan bentuk-bentuk partisipasi masyarakat dalam penyusunan RPJMDesa dan RKPDesa seperti memberikan saran dan solusi dari permasalahaan yang dihadapi oleh masyarakat desa. Selain itu, masyarakat juga memberikan sumbangan berupa barang atau alat-alat lain yang dibutuhkan seperti parang, gergaji, linggis termasuk memberikan tanah timbunan, pasir, batu kali, semen, dll, dan bantuan tenaga, terutama pada saat pembangunan mesjid sebagai rumah ibadah.

Tabel 4 di atas menunjukkan bahwa keikutsertaan masyarakat dalam pembangunan desa mencapai 97,57 persen dalam hal memberikan bantuan tenaga. Hanya 9,43 persen masyarakat yang tidak pernah memberikan bantuan tenaga dalam proses pembangunan desa. Sementara itu, bentuk keterlibatan masyarakat yang paling rendah adalah dalam memberikan material bangunan yang hanya 37,74 persen yang berarti bahwa sebanyak 62,26 persen responden tidak berpartisipasi.

Lebih jauh, Tabel 4 di atas juga menjelaskan bahwa perencanaan pembangunan dalam pelaksanaan program dana desa memenuhi prinsip partisipatif dan demokratis.
Dikatakan demikian karena pelibatan masyarakat dari berbagai unsur seperti para petani dan nelayan sebagai kelompok marginal, juga dilibatkan dalam pengambilan keputusan misalnya dalam pembuatan jalan permukiman dan pembangunan tambatan perahu di pesisir pantai Desa Tamalate. Selain itu, dalam pengelolaan dana desa, pemerintah desa juga memprioritaskan bidang pemberdayaan masyarakat. Berbagai kegiatan yang dilaksanakan dalam upaya pemberdayaan masyarakat seperti pelatihan peningkatan kapasitas masyarakat kelompok tani dan nelayan, kelompok perempuan, masyarakat miskin, dan kegiatan kepemudaan.Fakta ini menjelaskan bahwa perencanaan pembangunan Desa Tamalate memenuhi prinsip pemberdayaan dan kaderisasi. Dikatakan demikian karena pemerintah desa telah berupaya memberikan kekuatan atau power kepada masyarakatnya (empowering), dan pada saat yang sama pemerintah desa telah berupaya memberikan peluang kepada masyarakat di Desa Tamalate untuk bisa berkembang (enabling). Ini ditunjukkan dengan pelaksanaan program dana desa dengan membangun Pos Pelayanan Terpadu (Posyandu) dan peningkatan kapasitas bagi kader-kadernya, pembangunan drainase, perbaikan jalan tani, dan lain-lain. Dalam pelaksanaan pekerjaan kegiatan pembangunan tersebut pemerintah desa menggunakan tenaga kerja yang berasal dari desanya sendiri. Sebanyak 97,57 persen dari 265 responden memberikan jawaban ikut memberikan bantuan tenaga dalam kegiatan pembangunan desa.

Indikator lainnya dari pelaksanaan program dana desa dalam penelitian ini adalah pemanfaatan hasilhasil pembangunan. Hasil penelitian ini menjelaskan bahwa hasil-hasil pembangunan desa dimanfaatkan oleh masyarakat seperti rumah ibadah, Posyandu, gedung pendidikan anak usia dini, tambatan perahu, drainase, pengelolaan pasar desa, dan jalan antar pemukiman. Semua responden merasa bertanggungjawab dan berupaya untuk memanfaatkan serta melestarikan hasil-hasil pembangunan di desa.

\section{Tingkat Kohesi Sosial}

Kohesi sosial dapat dipahami sebagai kesatuan, keutuhan dan kepaduan dalam suatu upaya agar anggota kelompok tetap bertahan di dalam suatu komunitas. Kohesi sosial sebagai perasaan "we feeling" yang mempersatukan setiap anggota menjadi satu bagian (Myres, 2014: 280). Penelitian ini menggunakan empat indikator dalam menganalisis tingkat kohesi sosial, sebagaimana diungkapkan oleh Chavis et al. (2008: 3), yaitu Reinforcement of Needs (pemenuhan kebutuhan),

Tabel 4. Bentuk keterlibatan masyarakat dalam perencanaan pembangunan Desa Tamalate

\begin{tabular}{llcccc}
\hline \multirow{2}{*}{ No } & \multirow{2}{*}{ Bentuk Keterlibatan } & \multicolumn{2}{c}{ Pilihan Jawaban } & \multicolumn{2}{c}{ Persentase } \\
\cline { 3 - 5 } & & Ya & Tidak & 84,15 & Tidak \\
\hline 1 & Memberikan Saran & 223 & 42 & 15,85 \\
2 & Memberikan Solusi Permasalahan & 135 & 130 & 50,94 & 39,06 \\
3 & Memberikan Material Bangunan & 100 & 165 & 25,74 & 97,57 \\
4 & Bantuan Tenaga & 240 & 25 & 9,43 \\
\hline
\end{tabular}


Membership (keterlibatan sebagai anggota komunitas), Influence (memberikan pengaruh) dan Shared Emotional Connection (berbagi kontak emosional).Hasil penelitian terhadap keempat indikator tersebut, ditampilkan pada Tabel 5.

Tabel 5 di atas menjelaskan bahwa kohesi sosial masyarakat Desa Tamalate termasuk tinggi karena semua memberikan nilai di atas 90 persen. Keempat komponen indikator sense of community merepresentasikan tingkat kohesi sosial dalam masyarakat di Desa Tamalate yakni pemenuhan kebutuhan, keterlibatan anggota, memberikan pengaruh, dan berbagi kontak emosional. Indikator yang memiliki nilai paling tinggi adalah berbagi kontak emosional yang mencapai 100 persen. Sementara indikator memberikan pengaruh juga memiliki nilai yang tinggi tetapi dengan jumlah responden yang lebih rendah yakni 94,34 persen. Fakta ini menjelaskan bahwa sebagian besar masyarakat Desa Tamalate memiliki rasa komunitas yang kuat dan memiliki keterikatan yang tinggi antara satu dengan yang lain. Walaupun diketahui bahwa untuk indikator memberikan pengaruh diyakini hanya dimiliki oleh beberapa responden. Dikatakan demikian karena beberapa responden meyakini bahwa ada tokoh masyarakat yang mempunyai pengaruh di masyarakatnya.

Pemenuhan kebutuhan mencakup komunitas dapat memenuhi kebutuhan anggota dan komunitas, mereka memiliki perasaan "we feeling" yang mempersatukan setiap anggota, memiliki nilai-nilai yang dibagi bersama, serta mempunyai kesamaan dalam kebutuhan dan mengejar tujuan hidup yang sama. Sebanyak 98,11 persen responden memiliki rasa komunitas dalam hal pemenuhan kebutuhan yang tinggi. Ini disebabkan oleh keterikatan masyarakat yang tinggal dalam satu desa dan sudah hidup bersama sejak nenek moyangnya terdahulu. Mereka memiliki keterikatan darah antara satu keluarga dengan keluarga yang lain.

Keterlibatan anggota dalam komunitas dapat dilihat dari munculnya saling percaya diantara warga, mengenal satu sama lain, menggunakan banyak waktu dan tenaga untuk menjadi bagian dari warga masyarakat desa. Selain itu, keterlibatan anggota dapat juga dilihat dari keikutsertaan masyarakat dalam proses pembangunan desanya, mulai dari tahapan perencanaan pembangunan, pelaksanaan, dan pemanfaatan hasil-hasil pembangunan desa. Tabel 4 menunjukkan sebanyak 97,57 persen responden memberikan bantuan tenaga dalam proses pelaksanaan pembangunan desa. Hal ini dapat dipahami karena mereka adalah warga asli yang mendiami desanya dan membutuhkan pembangunan di desanya.

Selanjutnya, memberikan pengaruh adalah kemampuan anggota komunitas untuk memengaruhi anggota komunitas lainnya. Sebanyak 94,34 persen dari 265 responden yang memiliki pengaruh pada kondisi ling-kungan. Sedangkan 5,66 persen lainnya merasa tidak memiliki pengaruh pada kondisi lingkungan karena mereka menganggap ada warga masyarakat yang ditokohkan dapat memberikan pengaruh kepada lingkungan di komunitasnya. Responden yang merasa memiliki pengaruh terhadap kondisi lingkungannya karena sering memberikan saran atau masukan kepada anggota masyarakat yang lain atau kepada pemerintah desa, memberikan solusi pemecahan masalah dan bahkan diantara mereka merasa memengaruhi keberhasilan pembangunan desanya karena mampu memberikan bantuan material dalam pelaksanaan pembangunan desa sebagaimana ditampilkan pada Tabel 4.

Berbagi kontak emosional adalah anggota-anggota komunitas menjalani dan menikmati kebersamaan di dalam komunitas dan berbagi kejadian penting bersama. Berbagi kontak emosial dapat dilihat dari anggota sering berkumpul dengan anggota lainnya, merasa sebagai milik masyarakat dan sebagai anggota dari masyarakat desa, serta mereka lebih suka tinggal di desa Tamalate dibandingkan dengan di tempat lain dan tidak bermaksud pindah dari desanya. Sebesar 100 persen responden mengakui bahwa mereka telah memiliki kontak emosional yang tinggi. Mereka meyakini bahwa orangorang yang tinggal di desa Tamalate saling memahami, saling menghormati, dan saling membantu dalam rangka mewujudkan desanya sebagai tempat kehidupan dan penghidupan yang lebih baik. Mereka saling percaya dan membagi perasaan suka satu sama lainnya. Bahkan setiap ada acara yang dilaksanakan dengan sukarela mereka ikut, seperti melayat, pernikahan, sunatan, pengajian, dan yang lainnya, termasuk kegiatan yang diorganisir oleh pemerintah desa, misalnya sosialisasi, musyawarah dusun, penggalian gagasan, musyawarah desa, musrenbang desa, kegiatan kerja baktidan kegiatan sosial lainnya.

\section{Impikasi Program Dana Desa Terhadap Kohesi Sosial.}

Model summary hasil analisis program SPSS versi 20 menjelaskan nilai koefisien korelasi (R) adalah 0.547 dan R Square sebesar 0.300. Ini menjelaskan bahwa 30

Tabel 5. Persentase responden berdasarkan tingkat kohesi sosial

\begin{tabular}{|c|c|c|c|c|c|c|c|c|}
\hline \multirow[t]{2}{*}{ Kategori } & \multicolumn{2}{|c|}{$\begin{array}{l}\text { Pemenuhan } \\
\text { Kebutuhan }\end{array}$} & \multicolumn{2}{|c|}{ Keterlibatan Anggota } & \multicolumn{2}{|c|}{ Memberikan Pengaruh } & \multicolumn{2}{|c|}{ Berbagi Kontak Emosional } \\
\hline & $\mathrm{n}$ & $\%$ & $\mathrm{n}$ & $\%$ & $\mathrm{n}$ & $\%$ & $\mathrm{n}$ & $\%$ \\
\hline Ya & 260 & 98,11 & 254 & 95,85 & 250 & 94,34 & 265 & 100,00 \\
\hline Tidak & 5 & 1,89 & 11 & 4,15 & 15 & 5,66 & 0 & 0,00 \\
\hline Total & 265 & 100,00 & 265 & 100,00 & 265 & 100,00 & 265 & 100,00 \\
\hline
\end{tabular}


persen variabel kohesi sosial dipengaruhi oleh variabel pelaksanaan program dana desa. Sementara itu, koefisien korelasi (R) nilainya sebesar 0,547 yang berarti hubungan antar variabel berada dalam kategori sedang. Model linear antara variabel pelaksanaan program dana desa dengan variabel kohesi sosial dijelaskan oleh nilai sig $(0.000)<$ alpha (0.05) maka model linear antara variabel pelaksanaan program dana desa dengan variabel kohesi sosial signifikan. Selanjutnya koefisien regresi dapat dilihat pada Tabel 6 berikut:

Tabel 6. Koefisien Regresi Hasil Analisis Program SPSS versi 20.

\begin{tabular}{|c|c|c|c|c|c|c|}
\hline & \multirow{2}{*}{$\begin{array}{l}\text { Model } \\
\text { B }\end{array}$} & \multicolumn{2}{|c|}{$\begin{array}{c}\text { Unstandardized } \\
\text { Coefficients }\end{array}$} & \multirow{2}{*}{$\begin{array}{l}\text { Standardized } \\
\text { Coefficients }\end{array}$} & \multirow[b]{2}{*}{$\mathrm{t}$} & \multirow[b]{2}{*}{ Sig. } \\
\hline & & $\begin{array}{l}\text { Std. } \\
\text { Error }\end{array}$ & Beta & & & \\
\hline \multirow[t]{2}{*}{1} & (Constant) & 6.017 & .851 & & 7.072 & .000 \\
\hline & $\begin{array}{l}\text { Pelaksana- } \\
\text { an Program } \\
\text { Dana Desa }\end{array}$ & .539 & .051 & .548 & 10.625 & .000 \\
\hline
\end{tabular}

Sumber: Hasil Olah Data 2017

Tabel 6 tersebut menujukkan bahwa koefisien regresi dari persamaan linear $\mathrm{Y}=6.017+0.539 \mathrm{X}$. Koefisien korelasi (0.539), ini menjelaskan bahwa pelaksanaan program dana desa berimplikasi positif terhadap kohesi sosial masyarakat. Demikian juga untuk nilai Sig (0.000) $<$ alpha (0.05) menjelaskan bahwa pengaruh variabel pelaksanaan program dana desa terhadap kohesi sosial adalah signifikan. Dengan demikian, hipotesis penelitian ini terbukti bahwa ada implikasi positif pelaksanaan program dana desa terhadap kohesi sosial.

Hasil penelitian menunjukkan bahwa pelaksanaan program dana desa ternyata dapat memprediksi dalam arah korelasi positif tingkat kohesi sosial masyarakat di Desa Tamalate. Temuan penelitian ini sejalan dengan pendapat Faturochman (2006: 95) bahwa kohesi sosial semakin kuat jika interaksi masyarakat didominasi kerjasama bukan persaingan. Hasil penelitian ini juga sejalan dengan Daraba (2017: 56) bahwa program dana desa berpengaruh positif terhadap tingkat partisipasi masyarakat. Daraba (2017:56) dalam penelitiannya yang melibatkan 55 partisipan warga desa menunjukkan bahwa program dana desa memberikan kontribusi positif terhadap tingkat partisipasi masyarakat mulai dari memberikan saran, kritik, bantuan, atau pun terlibat aktif dalam proses pelaksanaan program. Selain itu, temuan penelitian ini juga sejalan penelitian Peters et al. (2010) bahwa kohesi sosial dapat dimulai dengan interaksi sosial yang bersifat informal dan sepintas lalu (cursory), misalnya mengobrol singkat, atau melalui sapaan "halo". Melalui interaksi sosial yang demikian itu, orang-orang merasa disambut, terhubung (connected) dengan warga rumah, dan sekaligus merasa seperti di rumah (feel at home).

Kohesi sosial masyarakat desa membuat anggota tidak bersifat individualis serta mampu menciptakan aksi- aksi kolektif dari masyarakat. Aksi kolektif masyarakat dan kekokohan kelembagaan masyarakat desa menjadi poin penting demi terciptanya kohesi sosial masyarakat. Hasil penelitian ini menjelaskan bahwa pelaksanaan program dana desa mulai pada tahap persiapan, musyawarah dusun, rembug desa, musyawarah perencanaan pembangunan desa (Musrenbang desa), pelaksanaan pembangunan desa, sampai kepada pelestarian dan pemanfaatan hasilhasil pemanfaatan pembangunan desa merupakan aksi kolektif masyarakat yang mampu merekatkan kohesi sosial masyarakat di Desa Tamalate. Temuan ini juga sejalan dengan penelitian Forrest et al (2001) di Amerika Serikat menyatakan bahwa kohesi sosial di tingkat masyarakat dapat berasal dari bentuk dan kualitas interaksi sosial di tingkat lokal dan keterlibatan masyarakat dapat meningkatkan kohesi sosial. Lebih jauh, Forrest et al (2001) mengatakan bahwa dalam model masyarakat modern, kohesi sosial dipandang sebagai proses bottom up.

Pengembangan kohesi sosial dapat berupa menjembatani kerjasama, rasa saling memahami, dan penciptaan kepentingan bersama, dapat menjadi dasar untuk mekanisme pencegahan konflik dan mempertahankan keutuhan yang berkelanjutan.Berdasarkan penelitian ini menunjukkan bahwa implementasi program dana desa yang penggunaannya dikuasakan kepada kepala desa selaku kuasa pengguna anggaran di desanya, dapat mengorganisir masyarakatnya dalam kelompok-kelompok kegiatan sebagai wujud nyata dari kegiatan pemberdayaan masyarakat dan pembangunan desa sekaligus menjadi jembatan kerjasama dan rasa saling memahami serta mampu menciptakan kepentingan bersama di desanya. Artinya bahwa kohesi sosial tercipta karena dengan pelaksanaan program dana desa masyarakat memiliki kemampuan untuk mendapatkan kualitas hidup yang lebih baik.

\section{SIMPULAN}

Pelaksanaan program dana desa berimplikasi positif terhadap kohesi sosial. Berdasarkan koefisien determinasi $\left(\mathrm{R}^{2}\right)$, kontribusi pelaksanaan program dana desa terhadap tingkat kohesi sosial adalah 30 persen. Koefisien korelasi (R) sebesar 0,547 yang berarti hubungan antar variabel berada dalam kategori sedang. Sementara itu, nilai koefisien regresi sebesar 0,539 dan nilai sig $=0,000$ yang lebih kecil dari alpha 0,05 masing-masing menunjukkan bahwa pelaksanaan program dana desa berimplikasi positif dan signifikan terhadap kohesi sosial. Pelaksanaan program dana desa mulai pada tahap persiapan, musyawarah dusun, musyawarah desa, musyawarah perencanaan pembangunan desa, pelaksanaan pembangunan desa, sampai kepada pelestarian dan pemanfaatan hasilhasil pemanfaatan pembangunan desa merupakan aksi kolektif masyarakat yang mampu merekatkan kohesi sosial masyarakat. Kohesi sosial tercipta seiring dengan 
munculnya rasa suka diantara anggota masyarakat dan interaksi yang terjadi didominasi kerjasama serta mempunyai tujuan yang terkait satu dengan lainnya.

\section{UCAPAN TERIMA KASIH}

Penelitian ini terselenggara atas biaya swadana dari tim peneliti. Namun demikian tidak akan terlaksana kalau tidak mendapat izin dari pimpinan. Untuk itu tim peneliti mengucapkan terima kasih kepada Direktur IPDN Kampus Sulawesi Selatan atas izin yang diberikan guna terlaksananya penelitian ini. Ucapan terima kasih juga disampaikan kepada pihak pemerintah Kabupaten Takalar. Demikian juga ucapan terima kasih kepada masyarakat di Desa Tamalate yang menjadi partisipan dalam penelitian ini.

\section{DAFTAR PUSTAKA}

Chavis, D.M., Lee, KS. \& Acosta, J.D. (2008). The Sense of Community (SCI) Revised: The Reliability and Validity of the SCI-2. Paper presented at the 2nd International Community Psychology Conference, Portugal: Lisboa.

Daraba, D. (2017). Pengaruh Program Dana Desa Terhadap Tingkat Partisipasi Masyarakat di Kecamatan Galesong Utara Kabupaten Takalar. Sosiohumaniora, 19, (1), 52-58.

Faisal, M. (2017). Modal Sosial Usahawan Pendatang di Kabupaten Takalar Provinsi Sulawesi Selatan. Sosiohumaniora, 19, (1), 70-76.

Faturochman, (2006). Pengantar Psikologi Sosial (Introduction to Social Psychology), Yogyakarta: Pustaka.

Forrest, R. \& Ade, K. (2001_. Social Cohesion, Social Capital, and the Neighbourhood?. Urban Studies, $38,(12), 2125-2145$.

Johnson, D.P. (1986). Teori Sosiologi Klasik dan Modern. Jilid 1, Jakarta: PT. Gramedia.
Kaslan, B. (2014). Kohesi Sosial. http://www.scribd.com/ doc/250553704/Kohesi Sosial Komunitas\#Scribd.

Kulig, J.C., Edge, D.S., Dana, S.E. \& Joyce, B. (2008). Understanding Community Ressiliency in Rural Communities Through Multidimethod Research. Journal of Rural and Community Development. http://www.jrcd.ca/viewarticle.php?id=181

Korten, D.C. (1988). Penyusunan Program Pembangunan Pedesaan: Pendekatan Proses Belajar Mengajar dalam David C Korten dan Syahrir, Pembangunan Berdimensi Kerakyatan, Jakarta: Yayasan Obor Indonesia.

Noorkamilah. (2008). Kohesivitas Remaja Islam di Kampung Sayidan, Prawirodirjan, Yogyakarta. http://digilib.uinsuka.ac.id/8368/1/Noorkamilah \%20kohesivitas\%20Remaj\%20Islam\%20di\%20 Kampung\%20Sayidan,\%20Prawirodirjan,\%20 Yogyakarta.pdf.

Nain, U. (2016). Sosiologi Pembangunan Desa, Jawa Barat. Sumedang: IPDN Jatinangor.

, (2017). Relasi Pemerintah Desa dan Supradesa Dalam Perencanaan dan Penganggaran Desa. Yogyakarta: Pustaka Pelajar.

Peters, K., Elands, B. \& Buijs, A. (2010). Social Interactions in Urban Parks: Stimulating Social Cohesion?. Urban Forestry \& Urban Greening, 9, (2), 93-100.

Primadona, (2001). Peran Penting Trust sebagai Energi Pembangunan Masyarakat. http://download.Portal garuda.org/article.php?article $=58207 \&$ val $=4377$

Ramdhani, N., \& Martono. (1996). Kohesivitas pada Masyarakat Miskin. http://ilib.ugm.ac.id.ezproxy. ugm.ac.id/jurnal/detail.php?dataId=4232

Soekanto, S. (2013). Sosiologi Suatu Pengantar. Jakarta. PT. Raja Grafindo Persada.

Sugiyono. (2003). Statistika Untuk Penelitian, Bandung: Penerbit: CV Alfabeta.

Trihendradi, C. (2012). Step by Step SPSS 20 Analisis Data Statistik. Yogyakarta: Penerbit Andi. 